\title{
Les estratègies de traducció d'Andreu Febrer en la seva versió de la Commedia de Dante
}

\author{
Raquel Parera \\ Universitat Pompeu Fabra \\ raquel.parera@gmail.com \\ https://orcid.org/OOOO-O0O2-0866-208X \\ Received: $07 / 04 / 2020 ;$ accepted: $27 / 04 / 2020$ \\ DOI: https://doi.org/IO.7203/MCLM.7.I70II
}

Andreu Febrer's translation techniques in his version of Dante's Commedia

Abstract

This paper studies the technique applied by Andreu Febrer in the verse translation of Dante's Commedia, in which he preserved both the metre and the meaning. The adopted point of view diverges from the usual appraising approach to this translation, describing instead the varied techniques used by the translator. The examples analised show a skilled and creative poet able to preserve the formal constriction without sacrificing the semantic accuracy with respect to Dante's

text.

\section{KeYwords}

Dante Alighieri; Divina Commedia; Divine Comedy; Andreu Febrer; medieval translations; medieval Catalan poetry; translation studies.

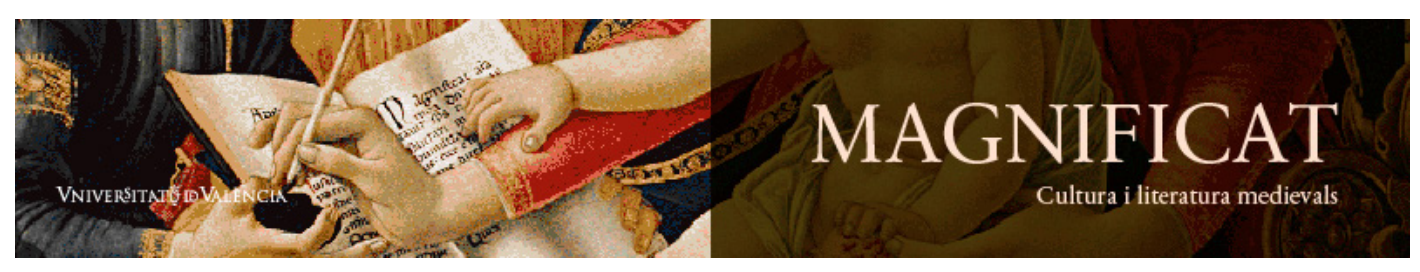

Magnificat Cultura i Literatura Medievals 7, 2020, I4I-I64. http://ojs.uv.es/index.php/MCLM

ISSN 2386-8295 
RESUM

En el present article s'analitza la tècnica de què se serví Andreu Febrer a l'hora de traduir en vers la Commedia de Dante, mantenint-ne tant el sentit com la forma mètrica. El punt de vista adoptat divergeix de l'enfocament valoratiu amb què s'havia examinat fins ara aquesta traducció, i se centra en la descripció de les diverses estratègies emprades pel traductor. Els exemples analitzats mostren un poeta destre i creatiu, que se sap adaptar a la constricció formal sense renunciar a la fidelitat semàntica envers el text de Dante.

PARAULES CLAU

Dante Alighieri; Divina Commedia; Andreu Febrer; traduccions medievals; poesia catalana medieval; traductologia

Raquel Parera. 2020. 'Les estratègies de traducció d'Andreu Febrer en la seva versió de la Commedia de Dante', Magnificat Cultura i Literatura Medievals, 7: I4I-I64, DOI: https://doi.org/IO.7203/ MCLM.7.I70I (cc) Br

Agraeixo a Lluís Cabré (Universitat Autònoma de Barcelona) les seves valuoses observacions.

\section{TAULA DE CONTINGUTS}

I Introducció - I43

2 Anàlisi de les estratègies del traductor - I 45

${ }_{3}$ Conclusions - ${ }_{5} 57$

4 Obres citades - I59 


\section{b米}

\section{Introducció}

El vigatà Andreu Febrer, algutzir del rei Alfons el Magnànim, fou el primer que gosà traduir la Commedia de Dante mantenint-ne la forma estròfica -la terza rima o tercet encadenat-, ja el I429. Molt probablement dedicà la seva traducció a aquest monarca apassionat de la literatura i seduït per Itàlia. ${ }^{1}$ La de Febrer és una versió ambiciosa, concebuda com a obra literària independent, ${ }^{2}$ que posa de manifest la seva destresa com a poeta. ${ }^{3}$ Representa un tour de force per l'època en què va ser confegida: les traduccions en vers d'obres en vers eren escasses en època medieval. Per aquesta raó, i per la importància de l'obra de Dante, figura ja entre les edicions de la primera Renaixença gràcies a Gaietà Vidal i de Valenciano (I878). Des de llavors s’ha analitzat sobretot pel seu valor en la història de la llengua catalana i atenent a la qualitat o naturalesa de la llengua del traductor. Els estudiosos han mirat d'avaluar si la traducció era o no correcta i han observat fins a quin punt incloïa préstecs o calcs de l'italià. Si fem un repàs de les valoracions de què ha estat objecte la versió de Febrer, observem que no totes són negatives, però la majoria comparteixen la tendència a avaluar la traducció des del punt de vista dels cànons hodierns, atribuint a Febrer la concepció actual de la llengua literària, més restringida que en el seu temps pel que fa a fronteres entre llengües. ${ }^{4}$ Fins i tot en els judicis més ponderats, que defensen l'obra del traductor, predomina la idea que Febrer se serveix de mitjans poc lícits, però excusables, per servar fidelitat al poema dantesc. ${ }^{5}$

Aquest punt de vista general no té en compte dues qüestions històriques d'ordre pràctic. La primera té relació amb la transmissió italiana: Febrer traduïa d'un antígraf que portava un text italià amb variants que sovint expliquen els seus suposats errors, de manera que si es compara la

I. La versió de Febrer només és precedida per dues traduccions en prosa: una al llatí, de Giovanni Bertoldi da Serravalle (I4I7), i l'altra al castellà, d'Enric de Villena (I428). També n’hi ha una traducció en hexàmetres llatins, de Matteo Ronto (I427-3I). Per al coneixement de Dante a la Corona d’Aragó, vegeu Gómez 2OI3: 3I-50, 20I6a i 20 6b. La identificació del Magnànim amb el dedicatari de la traducció s'argumenta a Parera 20I8: 5-53, que segueix un suggeriment de Riquer 1978: II7-I8. Febrer remarca el seu càrrec d'algutzir del rei en les rúbriques i en el colofó de la seva traducció, culminada a Barcelona el primer d'agost de I429. Només quatre mesos abans s'enllestia la versió catalana anònima del Decameron de Boccaccio, a Sant Cugat, coincidint amb l'entrada a Barcelona del monarca; vegeu Badia I973-74 i Renesto 2OOI.

2. No és el cas, per contra, de la traducció en prosa d'Enric de Villena, que havia de ser un ajut de lectura per al destinatari, el marquès de Santillana. De fet, en l'únic manuscrit conservat, trobem el text original de la Commedia a la part central, i la traducció copiada als marges. Vegeu Pascual I974: I5-66, i Cátedra 200O: XI-XIV.

3. Ens han pervingut quinze peces líriques de Febrer, datables a la darrera dècada del segle XIV (vegeu-ne l'edició a Riquer 195I). Segons Cabré-Torró 20I5, conformarien un cançoner dedicat a l'esposa de Martí el Jove, Maria de Sicília. La bibliografia sobre la lírica de Febrer és àmplia: remeto a Torró 20I4: 279-9O per a una visió de conjunt. Vegeu també Cabré r987 i 2007, Cabré-Torró en premsa, Pujol r988-89 i Pujol en premsa.

4. Prats (I988: IO4) assenyalava que "la idea de la clara diferenciació lingüística és també relativament moderna”.

5. Vegeu una ressenya de les diverses valoracions de la traducció de Febrer a Parera 20I8: 54-63, que se serveix de la bibliografia següent: Vidal i de Valenciano I869: 523-24; Miquel i Planas I9II-I4; Ribelles I9I5; Alòs I92I; Franquesa

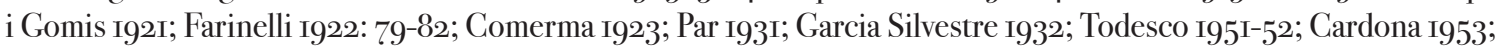
Rubió i Balaguer ı953: 790-9I; Ruiz Calonja ı954; Gallina ı957: 250-59; Brummer ı96o, I966, I986; Riquer I964: Io6II; Badia i Margarit I973; Gallina I974-88: I, 27-37; DECLC II, 853, III, 460, 68o, V, 337, i pàssim; Prats I988; NadalPrats I982-96; Closa I990; Fulquet 1999; Contreras 2OOO; Quer 2OoO; Di Girolamo 200I; Sansone 200I; Muñiz 2OO2: 83-84; Letizia 2007, 2008; Parera 2OO7; Piredda 2OO7; Benvenuti 2Oo8; Parera 2OIO; Pujol 2OI4: I54-I55; Marfany 2OI7: 8-II. 
versió catalana amb la Commedia tal com la reprodueixen les edicions modernes, es detectaran divergències entre el text català i l'italià que en realitat no són tals, sinó que les solucions de Febrer troben justificació en lliçons documentades en la transmissió italiana. ${ }^{6}$ La segona qüestió té a veure amb la concepció lingüística: Febrer traduïa d’una llengua literària a una altra llengua literària, i no del toscà al català parlat al segle XV. Per això, es podia sentir perfectament legitimat per introduir en la seva llengua literària d'arribada formes de la llengua poètica de tradició trobadoresca (i algun gal-licisme) i de la llengua poètica de Dante -algunes avui semblen calcs exagerats però d'altres s'haurien pogut introduir en la llengua poètica si el seu text hagués esdevingut modèlic. ${ }^{7}$ Febrer mateix explicita en les rúbriques inicials de les tres parts de l'obra i en el colofó que és "traslatada (...) de rims vulgars toscans en rims vulgars cathalans"; de fet és el primer testimoni que conservem de la consciència de l'ús del català com a llengua poètica. ${ }^{8}$ El traductor, doncs, considerava tots aquells termes plenament vàlids per a la llengua literària que estava creant i que intentà elevar a l'altura de Dante.

El criteri de correcció o naturalitat té valor per jutjar la capacitat del català medieval per anostrar una obra tan complexa, però no sembla el millor per avaluar la manera com Febrer es va haver d'encarar amb la Commedia. El criteri més just hauria de partir de la doble dificultat que s'imposà el traductor per respecte a la dignitat de Dante en tant que poeta: mantenir el metre i la rima dels tercets encadenats. Era un fet doblement insòlit, i així ho destacà el marquès de Santillana en el seu Prohemio e carta (I448/49): "Mosén Febrer fizo obras nobles, e algunos afirman aya traído el Dante de lengua florentina en catalán no menguando punto en la orden de metrificar e consonar". ${ }^{9}$ En aquest article, doncs, s'intentarà adoptar el punt de vista del traductor en el seu context: entenem que Febrer pretenia emular el Sommo Poeta, amb la novetat, la dificultat i també el prestigi que això comportava. El manteniment de la forma -el metre i la rima-, sense trair el sentit d'un text tan reverenciat, havia de ser el seu objectiu, i per assolir-lo es va servir de diverses estratègies i recursos

6. En la seva edició, Gallina (I974-88) consulta ocasionalment les variants italianes registrades a Petrocchi I966. A l'edició de Parera 20I8 l'examen i selecció de les variants italianes es fa sistemàticament, mot a mot, tenint també en compte les de Moore i889 i algunes altres, tasca que permet realitzar esmenes més fiables i justificar les solucions del traductor que podrien semblar errors o innovacions; vegeu-ne una anàlisi a Parera 2007.

7. Costanzo Di Girolamo afirma que la versió de Febrer "è in assoluto la prima traduzione in versi (nel metro originale) del poema, sostanzialmente fedele al testo italiano e di grande efficacia. Il suo interesse è anche di carattere linguistico, poiché è evidente, oltre alla consueta patina occitana, una patina italianizzante, che avrebbe potuto avere (ma non ebbe) il valore di proposta di un nuovo modello di lingua poetica”, i afegeix, a propòsit de l'adopció de l'endecasillabo italià en alguns versos (ho exemplificarem més avall), que "come sarebbe sbagliato considerare gli italianismi della traduzione dei sotterfugi di un traduttore pigro, allo stesso modo sarebbe ingenuo giudicare improvvisati i suoi decasillabi, molto poco tolosani. Febrer ha avuto l'intelligenza di sperimentare nella sua lingua un verso molto più variato e imprevedibile di quello occitano-catalano, un nuovo verso che avrebbe potuto, ma così non avvenne, sostituire il vecchio" (2003: 46-47; cito la versió italiana de l'article). Febrer es pot considerar, doncs, un traductor plenament conscient, característica ben esperable d'un gran poeta que va exercir una forta influència en els seus contemporanis i en les generacions posteriors, com per exemple en Jordi de Sant Jordi (Pujol I988-89 i Fratta 2005, pàssim) i Ausiàs March (Gómez-Pujol 2009: 256 i Pujol en premsa).

8. Vegeu Parera 20ıо: ı63-66. El marquès de Santillana també afirma que Febrer havia traduït Dante del florentí al català, com veurem més avall. L'elecció lingüística de Febrer es pot relacionar amb el canvi de llengua poètica -del provençal catalanitzat, anomenat llemosí, al català- que s'observa en els poetes de la cort del Magnànim (no solament en Ausiàs March) a partir del seu retorn d'Itàlia, com va mostrar Torró (2005 i 2009). Aquest canvi també es fa palès si comparem la llengua dels poemes conservats de Febrer amb la de la seva traducció de l’obra dantesca; tots els estudiosos han fet notar que en l’obra lírica és molt més occitanitzant (per exemple, Riquer ı95I: I4O-ı6o, Badia i Margarit ı73: 54, Gallina I974-88: I, 25, o Nadal-Prats I982-96: I4I).

9. Cito segons Rohland ı997: 22, eliminant la coma entre “catalán” i “no”. Per a les al·lusions de Santillana als poetes catalans en el Prohemio e carta, vegeu Cabré i998. 
que exemplificarem a continuació sense pretensions valoratives, classificatòries ni estadístiques, sinó solament descriptives. ${ }^{\text {IO }}$

\section{Anàlisi de les estratègies del traductor}

[г] Inf. I.64-8I

64 E com jo viu aquest al gran desert, "Hajes merçe de mi", cride a luy, "ques que.t sies, o ombra o home cert!".

67 Respos me ell: "No hom, home ja fuy; e pare e mare meus foren lombarts, de Mantova per patria amenduy.

7o Nasqui sots Julio, be que fos tarts; visqui en Roma sota.l bon August, en temps dels deus qu'eren fals e bugiarts.

73 Poeta fuy, e quante d'aquell just fill d'Anchise, qui puix vench lla de Troya, que l'ergulos Ilion fo combust.

76 Mas tu, per que tornes la via croya? Com no montes la serra delitosa qui es principi e cap de tota yoya?”.

79 "Est tu Virgili, aquella font joyosa qui espandist de parlar si larch flum?”, respongui jo ab cara vergonyosa.
Quando vidi costui nel gran diserto, "Miserere di me", gridai a lui, "qual che tu sii, od ombra od omo certo!". Rispuosemi: "Non omo, omo già fui, e li parenti miei furon lombardi, mantoani per patrïa ambedui.

Nacqui sub Iulio, ancor che fosse tardi, e vissi a Roma sotto 'l buono Augusto nel tempo de li dèi falsi e bugiardi.

Poeta fui, e cantai di quel giusto figliuol d'Anchise che venne di Troia, poi che 'l superbo Ilión fu combusto.

Ma tu perché ritorni a tanta noia? perché non sali il dilettoso monte ch’è principio e cagion di tutta gioia?”. "Or se' tu quel Virgilio e quella fonte che spandi di parlar sì largo fiume?", rispuos' io lui con vergognosa fronte.

\footnotetext{
66 o ombra] ombra $E$, o ombra $E^{2} \quad \mathbf{6}_{7}$ Respos me] Respos $E \quad 69$ Mantova] mantoca $E$, mantova $E^{2}$ 8I respongui] respongu $E$

$6_{4}$ E com jo] Quandi (Quand'i') Cha Parm Vat, Quandio Eg Fi La Lau Lo Pa Pr Ricc Tz 7o be que fos] ben che fosse Co, Moore (IL)
}

Io. Michela Letizia (2007) ha portat a terme un estudi de les rimes del conjunt de la Commedia -atès que és on es concentra el pes poètic- des del punt de vista de la fidelitat semàntica envers el text de partida, i inspirant-se lleugerament en la classificació establerta per Badia i Margarit (I973). Classifica les rimes en diverses categories: rime forzate, quan Febrer manté la rima de Dante (de vegades fins i tot el mateix mot), però no recull totalment el significat de l'original o bé en calca literalment un terme no documentat en català; traduzioni libere, quan el traductor no és literal però manté el sentit (pot conservar la mateixa rima o no); traduzioni sbagliate, quan Febrer no manté la rima i s'allunya del sentit; parole in rima no catalane, que provenen de l'occità o de l'italià. Si bé l'enfocament d'aquest estudi és diferent del nostre, resulta igualment interessant i ofereix abundants exemples. En les seves conclusions observa que de vegades el traductor afegeix a final de vers un adjectiu que no era en Dante, "ma che risulta appropriato", o bé reordena el vers, o afegeix adverbis, partícules, preposicions i perífrasis (p. II3). Efectivament, són algunes de les estratègies de què se serveix Febrer, com veurem al llarg de la nostra anàlisi. El punt de vista de Marta Marfany (2OI7: 8-II), en canvi, coincideix amb el que hem adoptat en aquest article. Marfany analitza la traducció dels vv. I27-I42 del cant V de l'Infern, especialment pel que fa al metre i a la rima, i documenta algunes de les fórmules emprades per Febrer en els trobadors i en la seva pròpia producció poètica. Vegeu també Letizia 2008, Parera 2007 i 20IO, i Marfany 2OI3. 


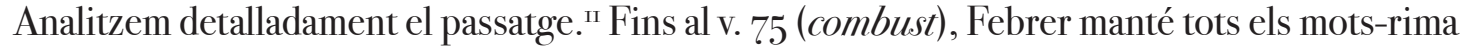
de Dante, servint-se de tots els recursos de què disposa, especialment l'ús d'elements italians i/o occitans. La primera sèrie de rimes (v. 62: it. offerto, cat. offert) no li presenta cap problema perquè només ha de traduir literalment els mots. En la segona només ho pot fer al v. 67 (fuy), mentre que als vv. 65 i 69 manté els mots-rima de Dante, lui i ambedui (sota la forma "amenduy"), que l'italià compartia amb l'occità i que formaven part, doncs, de la llengua poètica de Febrer (vegeu la variant formal anduy al poema I, 50). ${ }^{12}$ La tercera ve marcada per la traducció literal de lombardi en lombarts (v. 68); al v. $7^{2}$ ha de mantenir l'italià bugiardi ('mentiders'), catalanitzant-lo formalment en bugiarts, per mantenir la rima i el sentit; al v. $7 \mathrm{O}$ afegeix la $-s$ adverbial a tart (recurs que torna a utilitzar a Inf. II.8o per rimar amb guards i arts). En la quarta sèrie pot mantenir les dues primeres rimes literalment (August i just), mentre que en la darrera calca el llatinisme emprat per Dante (combust).

A la cinquena sèrie de rimes, però, Febrer es veu obligat a canviar un dels versos perquè ha de mantenir Troia (v. 74; com veurem més endavant, és habitual que els noms propis marquin les rimes); gioia (v. 78) es pot traduir literalment, però no pas noia (v. 76), de manera que canvia ritorni a tanta noia ('retornes a tanta angoixa') per tornes la via croya (que interpretem 'tornes a la via mesquina'), recorrent a l'adjectiu occità croya en posició de rima, mot que li devien suggerir les lectures poètiques que tenia interioritzades: al Diccionari de rims de Jaume March, en la rima en -oya hi apareixen els mots Troya, ploya, sauoya, croya, croya, monoya, joya, bloya i monjoya (Griera I92I: 46, 1l. 745-46), i retrobem la rima croya-Troya en un poema anònim, "Amor de cor hafectuos", on llegim: "preguen per me, donchs, que ten trist / se son estar en vida croya. / E requir ne Ector de Troya" (vv. 58-6o; font: RIALC). ${ }^{\text {r3 }}$ Cal notar, també, que el mot via del v. 76 és molt escaient, tenint en compte que l'obra de Dante narra el seu viatge al més enllà. El recurs de modificar el vers per mantenir la rima, sense trair el sentit de l'original, és, doncs, una altra estratègia de les utilitzades per Febrer.

La darrera sèrie del passatge exemplifica un fenomen ben diferent: Febrer decideix canviar la rima, mantenint els mots de l'original i modificant-ne l'ordre. En aquest cas concret, la rima podria ser perfectament mont, font i front. De fet, el primer mot i el darrer donen una rima força productiva al llarg de l'Infern: retrobem front i mont a XVIII, 3І i 33; XXI, 66 i 62; XXIV, I7 i 2I, rimant amb pont en tots tres casos; i a XXVII, 57 i 53, i XXXIII, 33 i 29, rimant amb pront en tots dos casos. La parella font i front també la trobem a XXV, 98 i Ioo, rimant amb pront. Val a dir que no en tots els

II. Les citacions del text italià provenen de Petrocchi i966; les del text de Febrer, de l'edició de Parera 2OI8. En primer lloc apareix l’aparat crític del text català, conservat en un únic còdex que actualment es troba a El Escorial amb la sigla L.II.I8 ( $E^{2}$ són les correccions executades per una segona mà; $E$ és la resta de contingut textual del manuscrit). A sota, l'aparat de variants italianes, és a dir, les lliçons de la transmissió italiana que justifiquen les solucions de Febrer, provinents, fonamentalment, de l'examen de les variants aportades per Petrocchi I966 i Moore i889 (vegeu, més amunt, la nota 6$)$.

I2. luy també apareix a les seves poesies (VII, 2I; XV, 79), però en femení, probablement per influència del francès, segons Riquer (ı95: 86). Sobre amenduy vegeu Prats ı988: IO2. Remetem al PD per als termes occitans al llarg de tota la nostra anàlisi.

I3. Trobem un cas similar a Inf. XIX.IOI-IO3-IO5: "la reverenza de le somme chiavi", "io userei parole ancor più gravi” i "calcando i buoni e sollevando i pravi”. Febrer decideix traduir literalment el primer vers, que és el més rellevant per al sentit: "la reverença de les sommes claus", i la rima en -aus li evoca altres mots que poden traslladar el sentit dels altres dos versos: braus, traduint gravi (“jo·t diguera de mots assats pus braus”) i maus, traducció literal de pravi ("baxant los bons e sus levant los maus"). Al Diccionari de rims de Jaume March, a la rima en -aus, hi ha la llista següent: Paus, repaus, claus, laus, laus, aus, aus, aus, braus, naus, corraus, leyaus, faus, maus, fraus (Griera I92I: 67, 11. I4I5I4I7). Retrobem les mateixes rimes, per exemple, en la cançó “El so que pus m’agensa” de Raimbaut de Vaqueiras: a la segona cobla trobem en rima Baus, chivaus, braus, vassaus, raus, claus i maus (font: Corpus des Troubadours). 
casos reprodueix l'original, sinó que de vegades se serveix d'aquestes rimes ja fixades per modificar un vers que no pot traduir literalment al català; ens referim a XXI, 62 (it. conte, cat. mont), i XXVII, 55 i XXXIII, 3 I (it. conte, cat. pront, en ambdós casos). No sabem per què el traductor va decidir canviar la rima; potser volia evitar que aparegués montes i mont en un mateix vers. Devia optar per invertir l'ordre de l'adjectiu i el substantiu a dilettoso monte (v. 77) i de seguida es va adonar que delitosa li permetia de rimar amb vergonyosa si realitzava la mateixa operació al darrer vers. Aquesta estratègia d'inversió d'adjectiu i substantiu és recurrent, i de vegades el traductor se'n serveix per mantenir les mateixes rimes de Dante. L'estructura resultant (substantiu + adjectiu), a banda de ser molt natural en català, li ofereix moltes més possibilitats de rima, ateses les característiques morfològiques dels adjectius. Al v. 79 el recurs és diferent: l'addició d'algun element que no apareix en l'original, en aquest cas l'adjectiu joyosa. És una de les estratègies més comunes al llarg de l’obra, atès que no solament permet aconseguir una rima, sinó que també completa el vers quan li manca alguna síl·laba (vegeu, per exemple, els rebles dels vv. 72, qu'eren, i 74, puix i lla). En general, Febrer s'inspira en el context a l'hora d'escollir el mot; en aquest cas, en yoya del vers anterior. Notem que aquí l'addició implica sacrificar alguns mots de Dante: Or se' tu quel Virgilio es redueix a Est tu Virgili.

A continuació s'examinarà la mètrica del passatge. El metre preponderant al llarg de la traducció de Febrer és el decasíl-lab català de patró $4^{+} 6$, però també hi trobem el decasílllab amb cesura lírica i un bon nombre de casos en què el traductor conserva el patró italià de l'endecasillabo, sense cesura. ${ }^{14}$ L'anàlisi mètrica del fragment que ens ocupa, tot i que no té cap pretensió estadística, ho corrobora. Així, observem que la major part dels versos d'aquest fragment són decasíllabs catalans amb el patró $4^{+6}$ (vv. 64, 65, 67, 72, 73, 75, 76, 80, 8I $)^{15} \mathrm{o}$ bé $3^{9}+6$, és a dir, amb cesura lírica, ben documentada ja en els trobadors (vv. 66, 74,77$){ }^{16}$ Vegem-ne alguns exemples:

$7^{2} \quad$ en temps dels deus qu'eren fals e bugiarts. $\left(4^{+} 6\right)$

nel tempo de li dèi falsi e bugiardi.

75 que l'ergulos Ilion fo combust. $\left(4^{+} 6\right)$

poi che ’l superbo Ilión fu combusto.

Aquests dos versos presenten l'estructura més habitual en la lírica catalana medieval: cesura després de la quarta síllaba tònica; l'accent recau damunt d'un mot oxíton o monosílllab. Vegem ara dos exemples de cesura lírica:

74 fill d'Anchise, qui puix vench lla de Troya, $\left(3^{\prime}+6\right)$

figliuol d'Anchise che venne di Troia,

77 Com no montes la serra delitosa $\left(3^{\prime}+6\right)$

perché non sali il dilettoso monte

I4. En les peces líriques conservades de Febrer, en canvi, el metre és sempre el decasíl lab català de patró $4^{+} 6$. Per a l'estudi de la mètrica de la traducció de la Commedia, vegeu Di Girolamo 200I, i 2003: 46 -48 (vegeu, més amunt, la nota 7). Per a la mètrica de Febrer remetem també a Serra-Baldó ı935, Tavani ı979a i i979b, Parramon I992, Duffell 2007: I54-I58 i I68, i Cabré 2008.

I5. En el cas dels vv. 64 i 65, si se’n fes una lectura sintàctica, l'accent recauria sobre la sisena síllaba, però notem que mètricament admeten un patró $4^{+} 6$ perfectament regular. Serra-Baldó (i935) també exemplifica aquest fenomen en els trobadors clàssics i conclou que "el criteri rigorosament estricte, mecanitzat, de la poètica medieval comporta una sobrevaloració del ritme, tant damunt de la sintaxi com de la prosòdia” (p. 28).

I6. Vegeu Di Girolamo 2003: 43-46, que analitza el decasíl-lab català en relació amb els seus models occitans. 
En els decasíl·labs, parlem de cesura lírica quan l'accent recau en la tercera síllaba i en un mot paroxíton; la síl-laba posterior a l'accentuada s'inclou en el còmput sil-làbic. Per exemple, en el v. 77, l'accent recau damunt de mon-, i la síl-laba següent, -tes, també es compta; altrament, el vers seria hipomètric. ${ }^{17}$

En canvi, els vv. 68, 69, 7O, 7I, 78 i 79, que no tenen cesura, es poden considerar endecasillabi amb diversos patrons accentuals. De la mateixa manera que Febrer manté mots italians, especialment a final de vers, per no modificar la rima de Dante, també adopta l'endecasillabo en alguns casos, per fidelitat a l'original. La presència d'un mot insubstituïble en el text italià, com ara un antropònim, un topònim o un gentilici, determina sovint l'elecció mètrica del traductor, tot i que no es tracta de cap regla general. En els versos que ens ocupen, hi abunden aquest tipus de termes: lombardi (lombarts, v. 68), mantoani (de Mantova, v. 69), Iulio (Julio, v. 7O), Roma (v. 7I), Virgilio (Virgili, v. 79). ${ }^{18} \mathrm{Al}$ v. 78, per contra, no hi apareix cap nom propi.

Vegem el patró accentual dels versos que hem considerat endecasillabi:

68 e pare e mare meus foren lombarts, (6a, IOa) e li parenti miei furon lombardi, (6a, IOa)

69 de Mantova per patria amenduy. (6a, IOa) mantoani per patrïa ambedui. (6a, IOa)

7o Nasqui sots Julio, be que fos tarts; (4a, 7a, IOa)

Nacqui sub Iulio, ancor che fosse tardi, (4a, 8a, IOa)

7I visqui en Roma sota.l bon August, (4a, 8a, IOa) e vissi a Roma sotto 'l buono Augusto (4a, 8a, IOa)

$7^{8} \quad$ qui es principi e cap de tota yoya?". (6a, Ioa) ch’è principio e cagion di tutta gioia?". (6a, IOa)

79 "Est tu Virgili, aquella font joyosa (4a, 8a, Ioa) "Or se' tu quel Virgilio e quella fonte (6a, IOa)

Notem que aquests versos de Febrer presenten els patrons accentuals habituals de l'endecasillabo: a la sisena síl.laba i a la desena; a la quarta, la setena i la desena, o a la quarta, la vuitena i la desena. ${ }^{19}$ A més, en quatre dels sis casos, el traductor manté el mateix patró accentual que l'original. Podem observar també uns petits -però importants- canvis en els dos primers versos: si traduís literalment e li parenti en e.ls pares i mantoani en mantoans, l'accent recauria en la cinquena sílllaba i li mancarien síl·labes per obtenir el decasíllab. Traduint-ho, sense trair el sentit, per $e$

I7. En la cesura èpica, en canvi, les síl-labes posteriors a l'accentuada s'exclouen en el còmput sil-làbic. Vegeu, per exemple, els vv. 7-8 del Sermó de Ramon Muntaner, escrit en alexandrins: “per est món e per l’altre, e que a salvació / vengon trestuit li comte, e vescomte e baró”; són compostos de dos hemistiquis de sis síl·labes, perquè les síl·labes -tre i -te no es compten. La cesura èpica és força excepcional en el decasíllab català.

I8. Serra-Baldó (I935: 26) n’ofereix altres exemples del mateix cant: “e entre feltre e feltre nexara” (v. I05), “per qui la verge Camilla mori” (v. IO7). La interpretació del v. IO5 és controvertida; alguns comentaristes van entendre Feltro com un topònim del Vèneto (Sapegno 2002: I3-I4). Examinant el context immediat d'aquests versos, hi trobem un altre endecasillabo farcit de noms propis: “Eurallo, Turno e Nixo perdut” (v. Io8), però més amunt n’hi ha dos més que no en contenen: "Terra ne piltre aquest jes no·s beura, / mas sapiençia, amor e virtut" (vv. IO3-IO4).

I9. Pazzaglia I990: 64. 
pare e mare i de Mantova, aconsegueix completar els versos i accentuar-los a la italiana, a la sisena síllaba.

Per acabar les consideracions sobre mètrica, a banda del que ja s'ha apuntat, també es podria destacar que en els versos de Febrer, en general, no hi ha diftong creixent en mots com patria (v. 69), Julio (v. 7O) o Ilion (v. 75), com és habitual en tota la poesia catalana medieval. També cal tenir present, a l'hora d'escandir els versos, que la llengua poètica medieval tenia una tendència a l'hiat molt més gran que no pas la moderna, especialment quan una de les vocals en contacte era tònica (vegeu cride $a$ al v. 65, visqui en al v. 7I, o qui espandist al v. 80), si bé els contactes vocàlics poden variar d'un vers a un altre per oferir un major ventall de possibilitats al traductor (per exemple, al v. Io8 es fa hiat en dues àtones diferents en contacte: "Eurallo, Turno e Nixo perdut", mentre que al v. 79 es fa sinalefa: "Est tu Virgili, aquella font joyosa").

A continuació centrarem l'anàlisi en l'ús de la llengua occitana que fa el traductor. Examinem-ne un parell de passatges.

\section{[2] Inf. III.4-9}

$4 \quad$ Justicia moch lo meu alt facthor; feu a mi la divinal potestatz, l'alta sapiencia e.l primer amor.

7 Abans de mi no fon altre creyats sino eternalls, e jo eternal dur. Lexats tota sperança, vos qu'intrats.
Giustizia mosse il mio alto fattore; fecemi la divina podestate, la somma sapïenza e 'l primo amore. Dinanzi a me non fuor cose create se non etterne, e io etterno duro. Lasciate ogne speranza, voi ch'intrate.

8 eternal] eternal Moore (Z)

Aquest fragment il·lustra una qüestió morfològica: la flexió sigmàtica. En occità, com a norma general, els substantius i adjectius masculins singulars es caracteritzen per la terminació en -s quan es troben en cas recte. En plural, per contra, el cas recte es declina sense la desinència -s. La traducció de Febrer abunda en exemples de flexió nominal occitana, especialment en posició de rima, com exemplifiquen aquests versos que transcriuen la inscripció de la porta infernal. Febrer, fidelment, tradueix intrate per intrats en el darrer vers, la qual cosa condiciona la rima dels versos $5 \mathrm{i}$ 7 (no és probable que sigui a la inversa, perquè podria haver usat perfectament les formes catalanes potestat i creat; en canvi, no li era possible emprar intrat). El recurs a l'occità ofereix les solucions potestatz i creyats; la segona és un exemple de flexió sigmàtica. La resta d'elements de la frase, que no es troben en posició de rima, concorden amb el participi creyats en cas (recte), gènere (masculí) i nombre (singular): així l'adjectiu eternalls i el pronom altre, que usualment no presenta la desinència $-s$ en cas recte. ${ }^{20}$

20. En trobem un altre exemple a Inf. XIV.IO7-Io9-III. En italià, els versos són: “e puro argento son le braccia e 'l petto", "da indi in giuso è tutto ferro eletto" i “e sta 'n su quel, più che 'n su l'altro, eretto". Febrer tradueix: "e pur argent son los brasos e.l pits", "d’aqui enjus es tot de ferro eslitz" (hem esmenat la lliçó del manuscrit "e silitz", que no feia sentit, en "eslitz”) i “sus cell esta plus que sus l’altre ergits”. Al v. Ioz la traducció és literal: pits és la forma pròpia del català antic (amb conservació de la -s etimològica), i apareix al llarg de la versió de la Commedia, també a l’interior del vers. En el v. Io9, per mantenir la rima, Febrer recorre al participi occità eslitz (del verb eslir, 'escollir'), amb flexió sigmàtica, que també aplica a ergits del v. III. 
[3] Inf. III.72-93

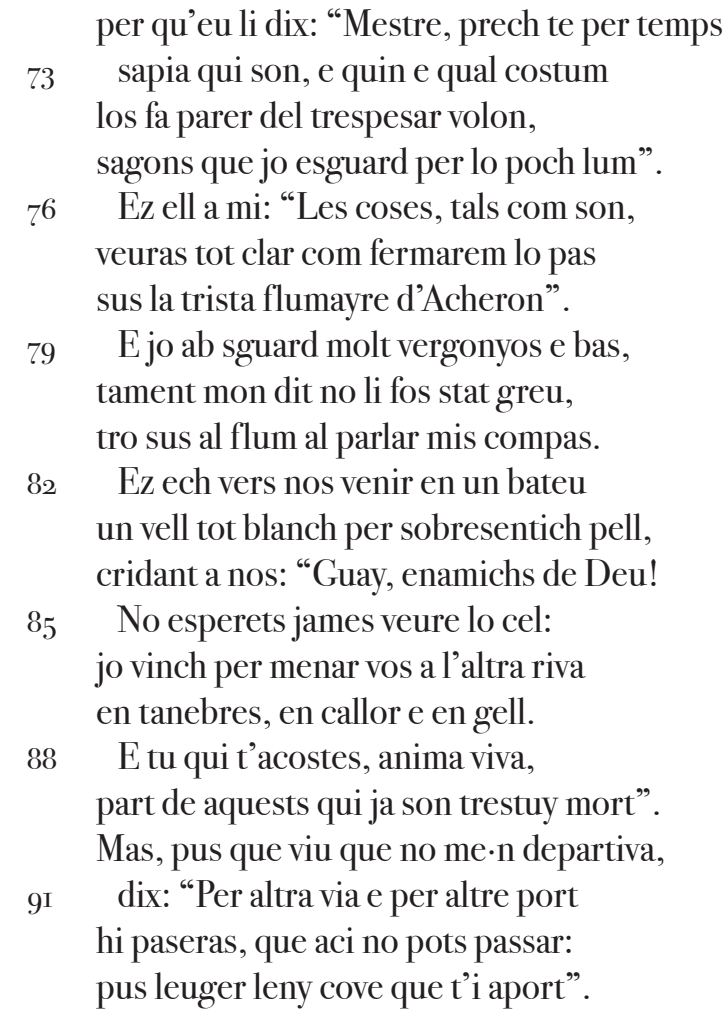

per ch'io dissi: "Maestro, or mi concedi ch'i' sappia quali sono, e qual costume le fa di trapassar parer sì pronte, com' i' discerno per lo fioco lume". Ed elli a me: "Le cose ti fier conte quando noi fermerem li nostri passi su la trista riviera d'Acheronte".

Allor con li occhi vergognosi e bassi, temendo no 'l mio dir li fosse grave, infino al fiume del parlar mi trassi.

Ed ecco verso noi venir per nave un vecchio, bianco per antico pelo, gridando: "Guai a voi, anime prave!

Non isperate mai veder lo cielo: i' vegno per menarvi a l'altra riva ne le tenebre etterne, in caldo e'n gelo.

E tu che se' costì, anima viva, pàrtiti da cotesti che son morti”. Ma poi che vide ch'io non mi partiva, disse: "Per altra via, per altri porti verrai a piaggia, non qui, per passare: più lieve legno convien che ti porti”.

$7 \mathbf{2}$ Mestre] mostre $E \quad 77$ fermarem] fermaren $E \quad \mathbf{7 9 - 8 0}$ e bas, / tament] e bas / Ebastament $E$ 83 sobresentich] sobresentich $E^{2}$ - pell] pell $E$, pel $E^{2} \mathbf{8}$ 4 cridant] cridat $E$ - a nos] auos $E$ - enamichs] enamjch $E \quad 89$ aquests] aquestes $E$

74 los fa] lor fa Eg, li fa Mad Parm Po Pr Urb, Moore (AC*DFKZ $A_{r}$ (?)) - parer del trespesar] parer del trapassar Co, parer di trapassar Cha Vat, Moore (FI) 75 per lo poch lum] in questo poco lume Moore (F) 79 E io] et io Moore (F) 85 james] già mai Moore (D) 9I e per altre] e per altri Pa (interlineat), Moore (D) 93 pus leuger] più leggier Moore (F)

Aquest passatge exemplifica diversos usos de la llengua occitana. Per començar, en el v. $7^{2}$ trobem el pronom personal $\mathrm{eu}$, que el traductor alterna amb la forma catalanajo en funció de les necessitats mètriques (vegeu tres versos més avall, per exemple, sagons que jo esguard). Al v. 74, en posició de rima, apareix l'adjectiu occità volon, 'desitjosos', traduint l'italià pronte (en referència a genti, que apareix al v. 7I). En italià, les rimes són pronte, conte i Acheronte. El traductor ha de conservar la darrera (v. 78), un topònim que no pot modificar, i ha de buscar dues paraules que rimin amb Acheron i li permetin mantenir-se fidel al sentit de l'original. D'aquesta manera, recorre a l'occità volon i a la modificació de l'italià tifier conte ('et seran explicades') en tals com son (v. 76). Podem observar, doncs, com Febrer ha meditat tot el passatge abans de decidir com el traduïa.

A la sèrie següent, al v. 79 apareix bas en posició de rima. Aquest adjectiu podria provenir de l'italià basso, però també coincideix amb l'occità bas, i apareix força al llarg de l'obra a final de vers (Inf. I.3O, V.IIo, VIII.Io8, etc.). Aquí bas, concordant amb sguard, rima amb pas (v. 77) i compas (v. 8I), mentre que en italià les rimes són bassi (concordant amb li occhi), passi i mi trassi ('em vaig controlar' les ganes de parlar). Febrer manté els dos primers mots en posició de rima (vv. 77 i 79 ), només canviant-los el nombre; per al tercer, en canvi, ha de buscar un equivalent, i el troba en mis 
compas, 'vaig posar mesura'.

Elv. 82 comença amb la conjunció $E z$, amb la $z$ antihiàtica pròpia de l'occità, que apareix sovint al llarg de la traducció (només a l'Infern, es registren una cinquantena de casos de $e z$, habitualment en correspondència amb l'italià ed; vegeu, més amunt, el v. 76). La paraula següent, $e c h$, que significa 'vet ací,, està documentada tant en italià (ecco) com en occità $(e c)$, i és freqüent en català antic (vegeu $D C V B$, s. v., i $D E C L C$, s. v. heus i heus aqui). El darrer mot del vers, bateu ('embarcació'), que tradueix l'italià nave, procedeix de l'occità. En aquest cas, el traductor ha mantingut la primera paraula de la sèrie de rimes (grave, en català greu, v. 80) i s'ha servit de l'occità (bateu) i d'una modificació (anime prave en enamichs de Deu, v. 84). Fixem-nos, doncs, que només conserva un mot-rima literal de l'original, però que gràcies al seu domini de l'occità pot traduir amb fidelitat el segon (nave), que segurament era el més difícil; per al tercer ha de trobar una solució diferent, com hem vist als vv. 76 i 8r; en aquestes ocasions d’innovació necessària s’observa la capacitat creativa del traductor: enamichs de Deu és un excel-lent equivalent d'anime prave.

En els versos següents (vv. 85-88), la similitud entre l’italià i el català facilita una traducció literal. A 89-9I-93, però, Febrer ha de recórrer de nou a l'occità. La traducció del verb del darrer vers (porti en aport) condiciona la rima dels precedents. El vers 9I es resol canviant el nombre del sintagma altriporti al singular (altre port), sense modificació substancial del sentit. En canvi, al vers 89 Febrer es veu forçat a mantenir el plural perquè es refereix a les ànimes (cotesti che son morti); per evitar trair la rima se serveix de la flexió occitana i tradueix che son morti en qui ja son trestuy mort ('que ja són tots morts'): l'adjectiu mort es troba en cas recte masculí plural, en concordança amb el pronom occità trestuy i amb la forma catalana aquests, que presenta la desinència $-s$ com és regular en català. No cal dir que això suposa un bon domini de la gramàtica occitana. Notem també que ja i trestuy no són a l'original i permeten al traductor de completar mètricament el vers, el qual segueix el patró $4^{+} 6$.

Continuem la il·lustració d'altres estratègies de traducció amb diversos passatges, sense fer-ne una anàlisi exhaustiva.

\section{[4] Inf. XVIII.I-I3}

I Loch ha infern appellat Males Voltes, de pedra tot e de collor ferrenya, com la cerca es qu'entorn les te revoltes.

$4 \quad$ Dret mig del camp maligne par que strenya tot buyt un pou assats ample e pregon, de qui en son loch dire ço que se.n denya.

7 Aquell cingle qui roman tot rodon entre.l pou e.l peu de l'alt ribaz dur, era distint en deu vallons al fon.

Io Com lla on per la guardia del mur molts, molts fossats tornejen los castells, la part e.l loch on son n'es pus segur,

I3 a tal semblant eran possats aquells;
Luogo è in inferno detto Malebolge, tutto di pietra di color ferrigno, come la cerchia che dintorno il volge.

Nel dritto mezzo del campo maligno vaneggia un pozzo assai largo e profondo, di cui suo loco dicerò l'ordigno.

Quel cinghio che rimane adunque è tondo tra 'l pozzo e 'l piè de l'alta ripa dura, e ha distinto in dieci valli il fondo.

Quale, dove per guardia de le mura più e più fossi cingon li castelli, la parte dove son rende figura, tale imagine quivi facean quelli;

2 e de collor] e di color Ash Cha Co Eg Fi Ga La Lau Laur Lo Mad (coll-) Mart Pa Parm Po Pr Rb Ricc Si Tz Urb Vat, Moore (ABCDEGHIMOPZCD) 4 Dret mig] Dritto nel meçço Ham

6 en son loch] in suo loco Moore - se·n denya] lor digno La Pa Rb, Moore (C), lor degno Mad (e corr. i) 7 roman tot rodon] rimane adunque tondo Ash Co Eg Fi (add-) Ga La Lau Lo Pa Parm (add-) Pr Ricc Tz 
9 era distint] era distinto Co Eg Fi Ga La Lau Laur Lo Mad Pa Parm Po Pr Ricc Triv Tz, Moore (ADEFGHMOPQ) - al fon] in fondo Co, al fondo Moore (Q) io Com lla on] Come doue Co I2 n'es pus segur] rende sigura Ham, r. segura Rb, r. sicura Cha, Moore (ABCDFGIKMPZ $\left.A_{2} C D\right)$

En primer lloc, cal observar que el canvi de Malebolge en Males Voltes no es deu a la rima d'aquesta sèrie, sinó que és l'opció de traducció que Febrer ha escollit per a Malebolge; en la resta de casos no apareix en posició de rima (vegeu Males Voltes als epígrafs dels cants XVII i XVIII, i a XXI.5; Malavolta a XXIV.37 i XXIX.4I). Alv. 3 trobem una petita modificació per la rima: il volge ('l'envolta') traduït per les té revoltes (perquè es refereix a Males Voltes), i un canvi d'ordre per la mètrica: el verb es després de cerca (devia interpretar com è), amb el qual aconsegueix un decasíl-lab amb l'estructura $4^{+} 6$.

Passem als vv. 2-4-6. Febrer decideix mantenir ferrigno -que determina la rima de la sèrie-, però ha de canviar el gènere de l'adjectiu perquè, en el català de l'època, color era femení. Manté el motrima, doncs, però amb un canvi de gènere, i la rima serà en -enya. En el v. 4, que a l'original acaba amb maligno, hi afegeix par que strenya, sense substituir cap mot de l'original; aquesta addició, que l'ajuda a completar mètricament el vers, no és gratuïta: Febrer tradueix el verb vaneggia del vers següent (que els diccionaris defineixen com "aprirsi di un vuoto, di una cavità") per par que strenya / tot buyt. Elv. 6 podria semblar una modificació substancial de l'ordigno, però si mirem com separen les paraules diversos manuscrits italians (lor digno) i consultem la traducció de Villena (lo que.l'pertenesçe), podem entendre la versió de Febrer: ço que se.n denya. Pel que fa a la mètrica, destaca el canvi d'ordre del v. 2 (tutto di pietra en de pedra tot), que li permet crear un decasíllab amb l'estructura $4^{+} 6$.

Els vv. 8-IO-I2 ens ofereixen un altre exemple de canvi de gènere, en aquest cas, motivat per la rima: si hagués traduït ripa dura en riba dura, no hauria pogut traduir literalment el v. Io (de le mura en dels murs), ${ }^{21}$ de manera que en lloc de riba empra el mot masculí ribaz ('ribàs') perquè dur rima amb mur. En el v. 8, doncs, canvia el gènere, i en el to el nombre (passa del plural mura al singular mur). El v. I2, com el v. 6 , pot semblar una innovació de Febrer, però la variant italiana rende sicura, àmpliament documentada, explica la solució n'es pus segur, amb el canvi de gènere requerit per la rima, que aconsegueix afegint $e$.l loch, addició que també l'ajuda a completar el vers mètricament (observem que en resulta el doblet sinonímic la part e.l loch).

En els v. 5-7-9, en canvi, manté la rima sense dificultats (profondo, tondo, fondo). Devien ser rimes habituals; tots tres mots apareixen al Diccionari de rims de Jaume March (preyon, redon, fon), juntament amb més d'una vintena d'altres mots acabats en -on (Griera I92I: 62, 11. I263-I267). El pou pregon recorda el v. 26 del poema VIII del mateix Febrer: "lo preyon potz de l'infernal abisme", peça que conté reminiscències dantesques als vv. $33-36{ }^{22}$ Per altra banda, en el poema IX, Febrer rima preyon amb fon (vv. 6-7).

Per acabar, el v. I3 tradueix l'italià mantenint-ne el sentit, però en termes diferents; la substitució de tale imagine per a tal semblant (sinònims que ja trobem aparellats en la Bíblia) produeix un decasíl-lab d'estructura $4+6$. Del vers original conserva el mot-rima, quelli (aquells), com també els altres dos de la sèrie, castelli (castells, v. II) i ponticelli (pontixells, v. I5).

2I. Tanmateix, a Inf. IV.Io? ha traduït alte mura en alta mura, que el DCVB considera un italianisme, tot i que també es documenta en occità com a substantiu femení, 'mur' (PD, s. v. mura).

22. Vegeu Riquer 195I: 55, Torró 2014: 282, i Parera 20I8: 43-44. 
[5] Inf. XVII.49-63

49 no altrement que fan d'estiu los cans, ar del cap, ar dels peus, com son morduts de mosques o puces o de tavans.

$5^{2} \quad$ Pusqu'al lur vis mos vulls hagui moguts, lo qual cell doloros foch fer e quasca, no.n conegui un; mas fuy percebuts

55 qu'all coll de tots penjava una tasca ab cert senyal e ab certa color, e d'aço par que.l vis de lor se pasca.

$5^{8}$ Com jo, guardant, fuy vengut entre lor, sobre una bossa d'or viu atzur eu qui d'un leo forma havia e tenor.

6I Puys, procehint lo tret del sguart meu, un'altra.n viu, qu' era com a sanch rossa, mostrant una ocha blancha plus que neu. non altrimenti fan di state i cani or col ceffo or col piè, quando son morsi o da pulci o da mosche o da tafani.

Poi che nel viso a certi li occhi porsi, ne' quali 'l doloroso foco casca, non ne conobbi alcun; ma io m'accorsi che dal collo a ciascun pendea una tasca ch'avea certo colore e certo segno, e quindi par che 'l loro occhio si pasca. E com' io riguardando tra lor vegno, in una borsa gialla vidi azzurro che d'un leone avea faccia e contegno.

Poi, procedendo di mio sguardo il curro, vidine un'altra come sangue rossa, mostrando un'oca bianca più che burro.

$\mathbf{5 3}$ quasca] guasca $E \quad \mathbf{5 5}$ tasca] casca $E \quad \mathbf{5 7}$ de lor] dolor $E$

5 I de mosques o puces o de tavans] / da mosconi da pulci o da tafani $C o 53$ lo qual] nel qual(e) Ham Po, Moore (DI) 55 qu'all coll de tots] Chal collo di ciaschun Ham, che al collo di ciascuno Moore (D), Che al collo a c. Mad, Moore (E)

Comentarem només alguns aspectes rellevants de la traducció del passatge. Al v. 54 notem la forma percebuts, en flexió occitana (cas recte), per tal de rimar amb morduts (v. 50) i moguts (v. $5^{2}$ ). En aquest cas, Febrer ha preferit traslladar literalment morsi (v. 5O) i adaptar els altres dos versos a la rima en -uts, mantenint-ne intacte el significat. Al v. 53 destaca l'addició de fer e ('fereix i'), escaient en el context, que aporta dues síllabes que mancaven en la traducció literal i forma un doblet sinonímic amb quasca. Passem als vv. 56-58-6o, on, un cop més, davant de la impossibilitat de mantenir les rimes de Dante, l'estratègia utilitzada és l'alteració de l'ordre dels elements de l'original. Febrer devia detectar que gràcies a aquest recurs podia rimar fâcilment els vv. $5^{6}$ i $5^{8}$, canviant certo colore e certo segno en cert senyal e (...) certa color, i tra lor vegno en fuy vengut entre lor, i també el v. 6o, traduint contegno per tenor i alterant avea faccia e contegno en forma havia e tenor. Probablement la seva professió notarial li va suggerir el binomi forma e tenor, habitual en la documentació. ${ }^{23}$ Per altra banda, al v. 56 fa una petita modificació per la mètrica: substitueix ch'avea per $a b . . . a b$; la traducció literal hauria provocat hipermetria. Les rimes dels vv. 53-55-57, per contra, s'han mantingut, cosa que ha implicat conservar el terme italià tasca.

La sèrie més interessant, però, és la dels vv. 59-6I-63, on la tercera rima determina les altres dues. Febrer no pot conservar les rimes de Dante; només la primera forma coincideix en ambdues llengües (azzurro-atzur). La comparació del color de l'oca del v. 63, en italià bianca più che burro, li devia suggerir la fórmula més habitual blanca plus que neu, que rima amb el v. 6I alterant l'ordre de l'italià di mio sguardo il curro en lo tret del sguart meu, i amb el v. 59 afegint a final de vers el pronom occità eu. Aquesta addició al v. 59 provocaria hipermetria si traduís literalment gialla en groga; per això opta pel metafòric d'or, tan habitual per designar aquest color com la neu per al blanc.

23. Andreu Febrer era notari de professió. Vegeu Torró 2OI4: 279, i Parera 2OI8: 2O-2I. 
[6] Inf. XVIII.86-99

Ell es Jason, qu'ab seny e ab coratge del molto d'or los Colchos privats fe.

88 Passa l'isla de Lenno, e pel ribatge, despuys que les fembres despiedades dels mascles lurs tots feran gran carnatge;

9I la ab senyals e ab paraules ornades

Ysiphile trompa, la joveneta qui primer hac les altres enganades.

94 Lexa la aqui, prenyada e soleta; de tal culpa aytal martir li part; e de Medea.s fa venjança streta.

$97 \quad$ Ab ell se.n va qui decep de tal part. E bast a tu aço del primer vall saber, e d'aquells de qui est ben fart".
Quelli è lasón, che per cuore e per senno

li Colchi del monton privati féne.

Ello passò per l'isola di Lenno

poi che l'ardite femmine spietate

tutti li maschi loro a morte dienno.

Ivi con segni e con parole ornate

Isifile ingannò, la giovinetta

che prima avea tutte l'altre ingannate.

Lasciolla quivi, gravida, soletta;

tal colpa a tal martiro lui condanna;

e anche di Medea si fa vendetta.

Con lui sen va chi da tal parte inganna;

e questo basti de la prima valle

sapere e di color che "n sé assanna".

$\mathbf{8 8}$ l'isla] lisba $E$ 9o feran] faran $E$

94 $\mathrm{e}$ soleta] e solecta Ash Cha Co Ga Laur Vat, e soletta Moore

Observem les rimes d'aquest passatge presidit per Jàson, personatge que el traductor coneixia bé, com demostra la seva presència en el poema $V$ de Febrer: "no fon Jason del velhor conquistar / quan los perilhs del drach fer poch sobrar, / e may dels bous qui.l cuydaren aucire" (vv. $3 \mathrm{O}-32$ ). Fixem-nos també que al v. 87, on Dante només parla del monton, Febrer hi afegeix d'or per obtenir la síllaba que li manca; a més, trasllada el sintagma al principi del vers per aconseguir el patró accentual $4^{+} 6$.

Les rimes dels vv. 86-88-9o no corresponen a les de Dante i demostren, una vegada més, que el traductor llegia primer tot el fragment. En aquest cas, al v. 88 a l'original hi ha el topònim Lenno en posició de rima. Febrer ha de mantenir el terme, però l'ha de desplaçar a l'interior del vers perquè en català no pot rimar amb -enno. ${ }^{24}$ Probablement és el primer vers de la sèrie que li suggereix la solució: canviant l'ordre de per cuore e per senno obté ab seny e ab coratge; el mot coratge li evoca altres rimes en -atge del seu thesaurus mental, propi d'un poeta experimentat. En la seva obra lírica conservada trobem en rima salvatge, pelatge, viatge i carnatge al poema IX; coratge, salvatge, dampnatge, omatge, ostatge, eretatge, menatge, guatge i peratge al poema XIV; hostatge, alegratge, pessatge i visatge al poema VII, i linatge al poema I. No hi apareix ribatge, ${ }^{25}$ però sí que trobem aquest mot en rima en els trobadors. A tall d'exemple, observem les rimes en -atge al cinquè i vuitè vers de cada cobla, i al primer de la tornada, del poema "Be·m platz lo gais temps de pascor" de Bertran de Born: boscatge, alegratge, coratge, ribatge, vassalatge, agradatge, aratge, paratge,

24. Passa el mateix a Inf. XX.78, on en italià apareix Po rimant amb mette co ('comença', v. 76) i può (v. 74): "ciò che 'n grembo a Benaco star non può, / e fassi fiume giù per verdi paschi. / Tosto che l'acqua a correr mette co, / non più Benaco, ma Mencio si chiama / fino a Governol, dove cade in Po". Febrer no pot mantenir les rimes, però vol restar fidel a l'original; alterant els termes del primer vers, star non può, en no pot star, aconsegueix una rima més fâcil: només necessita dos infinitius de la primera conjugació. Així, tradueix a correr mette co per s pren a 'vallar i dove cade in Po per on se va al Po mesclar, solucions totalment adients al context.

25. Tampoc no figura en el Diccionari de rims de Jaume March. En la rima amb -atge hi ha la llista següent: viatge, outratge, senyoratge, paratge, linatge, languatge, guiatge, passatge, dampnatge, coratge, bernatge, misatge, alegratge, saluatge, boscatge, romiatge, auantatge, vsatge, [estatge], prestatge, fformatge, rematge, visatge, viatge, hostalatge, estatge, guatge (Griera I92I: 47, 11. 777-782). Una desena d'aquests termes coincideixen amb les rimes de les poesies de Febrer. 
ombratge, erbatge, lignatge, maestratge, gatge.$^{26}$ Cinc coincideixen, a més, amb la lírica de Febrer. Era un conjunt de rimes finit i recurrent, que s'anaven combinant.

El mot coratge, doncs, suggereix a Febrer com traduir el passatge: al v. 88 afegeix e pel ribatge, en referència a la riba de l'illa, i al v. 90 modifica a morte dienno en feran gran carnatge, sense trair el sentit i fins i tot potenciant la imatge. ${ }^{27}$

Avancem fins al v. 96. Febrer ha traduït literalment els mots-rima dels vv. 92 (giovinetta) i 94 (soletta), però no ho pot fer amb vendetta (v. 96), de manera que manté el mot, però afegeix l'adjectiu streta en posició de rima. L'addició d'aquest adjectiu és un recurs que trobem en altres passatges, com ara Inf. I.2I, "ab pietat streta"; XIV.I6-I7, "O venjança de Deu! E com estreta / pahor deus fer a cascun hom qui lig", o XXVI.94, "ne pietat estreta".

La darrera sèrie de rimes del fragment no es pot traduir literalment. Probablement Febrer va observar que, simplement canviant l'ordre a da tal parte inganna (v. 97), podia obtenir una rima amb part (decep de tal part), i va optar pels rims equívocs, tradicionals en la pràctica del trobar ric i amb secció separada en el rimari de Jaume March; així, al v. 95 modifica tal colpa a tal martiro lui condanna en de tal culpa aytal martir li part, on part significa 'sorgeix, ve'. ${ }^{28}$ En el darrer vers (99), per contra, el canvi de sentit és substancial. L'original, che 'n séassanna ('que a dins seu mossega'), es tradueix en de qui est ben fart. La innovació de Febrer, però, no és tan agosarada si llegim el darrer vers del cant (I36): "E quinci sian le nostre viste sazie" ("E-lls nostres ulls sian sadolls d'aço", en la versió catalana). El traductor s’inspira en el context, com ja hem vist a Inf. I.79 ([r]), a l’hora de modificar el text; i aquest cas demostra, a més, la lectura d'un llarg fragment (segurament del cant sencer) abans d'emprendre'n la traducció. Aquesta manera de fer demostra com, a pesar de la volguda fidelitat a la lletra, Febrer no traduïa verbum verbo, sinó d'una manera més moderna, amb “cops d'ala intel-lectuals", per dir-ho com Josep Carner. Un altre exemple el trobem a Inf. XIX.89: "ch'io respongui paraula vertedera", traduint "ch'i” pur rispuosi lui a questo metro"; Febrer tradueix literalment els mots Pietro (v. 9I) i retro (v. 93) en Pere i derrera, però ha de modificar questo metro; l'elecció del sintagma paraula vertedera no és casual: prové del v. I23, "lo suon de le parole vere espresse”. El traductor, doncs, modifica el vers quan és necessari, però intentant mantenir els mots de Dante.

$\mathrm{Al}$ cant XVI n’observem un altre cas, però aquí Febrer no troba la solució més endavant, sinó en el cant precedent.

26. També es documenta ribatge en poetes posteriors a l'obra de Febrer, com Ausiàs March (rimant amb coratge, LXVIII, vv. I8-I9), Ausiàs de Sant Joan ("Si dels infels Polifemo y Golies”, v. 34), Bernat Serra ("Pus so destret no·m tenguats a follia", v. 3I; al v. I4 hi apareix carnatge) o Jaume Roig (Espill, v. 57O). Pel que fa a carnatge, es troba, per exemple, al v. 23 del poema “A Dieu done m’arma de bon'amor” de Raimon Gaucelm de Bezers (als vv. I3 i 43 hi apareix coratge), i en poetes posteriors com Ramon Savall ("De mal saber, ab verinos coratge", v. 22; coratge apareix als vv. I i 40), Pere Tresfort (“Gran carrech han huy tuyt l'om de paratge", v. 25), el ja citat Bernat Serra o la traducció catalana de Frondino e Brisona (v. 8o). Fonts: Corpus des Troubadours, RIALC.

27. Trobem un cas paral-lel a Inf. VII.80-82-84: Febrer canvia les rimes i també escull la terminació en -atge. En italià els mots en rima són sangue, langue ('llangueix, s’afebleix') i angue ('serp'). El procediment és el mateix que en altres casos: canviant d'ordre els termes del v. 84, come in erba l'angue, en resulta com la serp en l'erbatge; aleshores tradueix sangue per linatge, que té el mateix sentit en aquest context, i modifica lleugerament e l'altra langue en altres son en servatge, conservant metafòricament el significat. Notem que el primer mot en rima, linatge, ja apareix a les poesies de Febrer, i també, juntament amb el tercer, erbatge, al poema de Bertran de Born citat més amunt; els retrobem tots dos, per exemple, en el poema “Tant es lo mons ples d'amor descorteza” de Joan de Castellnou (vv. 20 i 47 ). Fonts: Corpus des Troubadours, RIALC.

28. També trobem rims equívocs en les poesies de Febrer, com XIV, vv. 77-78 i 2I8-2I9, o XV, IOI-IO2, i en altres passatges de la Commedia; per exemple, al cant XIV, vv. I7 i 2I, legge en Dante (en el sentit de 'llegeix’ i de 'llei'), que es tradueix literalment en lig; el v. I9, en canvi, es modifica sàviament: “D’anime nude vidi molte gregge” esdevé “D’esperits nuus viu un molt gran trepig”. Per a un estudi de les rimes de mèrit vegeu Cantavella 2O2Oa i $2020 b$. 


\section{[7] Inf. XVI.6I-66}

6I Lex l'amarg fel e vaig per lo dolç pom a mi promes per cell qu'es mon govern; mas al centre primer cove que tom".

64 "Si longament ta anima govern los membres teus", respos aquell lahora, "e si ta fama apres tu se etern.
Lascio lo fele e vo per dolci pomi promessi a me per lo verace duca; ma 'nfino al centro pria convien ch'i' tomi”'

"Se lungamente l'anima conduca le membra tue", rispuose quelli ancora, "e se la fama tua dopo te luca,

64 Si longament] Silongoment $E \quad \mathbf{6 6}$ etern] entern $E$ 65 lahora] allora Ash Co Laur Pr, Moore (D)

El traductor es veu obligat a canviar les rimes dels vv. 62-64-66. La semblança lèxica de duca (v. 62) i conduca (v. 64) li deu suggerir la traducció en rims equívocs; així, lo verace duca esdevé cell qu'es mon govern, i conduca es tradueix per govern. Li resta la tercera rima, luca, potser la més difícil. La memòria del traductor, però, li evoca les paraules que Dante ha dirigit a Brunetto Latini en el cant anterior (v. 85), en què s'empra el verb eternar referit a la fama: "m'insegnavate come l'uom s'etterna" (“m'ensenyavets co·s fa l'hom eternal” en la versió catalana). Febrer, doncs, tradueix luca per se etern, innovació que li aporta la rima que li mancava i li permet mantenir el sentit $i$ alhora la fidelitat als mots del Sommo Poeta.

No és la primera vegada que el traductor s'enfrontava amb luca en rima.

[8] Inf. IV.I48-I5I

I48 La companya de sis en dos se scema; per altra part mena lo sage escorta fors dels retrets mi, en l'ayre qui trema.

I5I E vinch en loch on tota lum es morta.
La sesta compagnia in due si scema: per altra via mi mena il savio duca, fuor de la queta, ne l'aura che trema.

E vegno in parte ove non è che luca.

$\mathbf{I 5 O}$ retrets] racrets $E$ - en] eu $E$ - trema] crema $E \quad$ I5I on] om $E$ 150 ayre] aira $A s h$, aer $C o U r b$, aere $P r$

En aquest cas ha traduït ove non è che luca per on tota lum es morta (i duca per escorta). La bella solució de Febrer s'inspira en el context general de l'Inferno, on predomina la idea de la mort. Hi ha altres exemples de la competència lingüística del traductor, com ara el v. 46 del cant XVII, on tradueix "Per li occhi fora scoppiava lor duolo" en "Pels ulls deffors los degotava 1 dol", o els vv. IOO-IOI: "Come la navicella esce di loco / in dietro in dietro, sì quindi si tolse" esdevé "Com la barqua fa quant ix de son loch / ab la popa denant, axi-s leva”. Els vv. 74-75 del mateix cant ens ofereixen una imatge menys elegant, però en consonància amb la varietat de registres emprats per Dante al llarg de la Commedia: per rimar amb bochs (v. 73, it. becchi), tradueix "Qui distorse la bocca e di fuor trasse / la lingua, come bue che 'l naso lecchi" per "Aqui torçe la cara e trasch defora / la lengua, com fa.l bou qui.s lepa.ls mochs", descrivint exactament la mateixa escena que l'original.

Hi ha ocasions en què el traductor encara és més creatiu, com ara al v. Ig del cant XVII, on concep una imatge nova. L'italià diu: "Come talvolta stanno a riva i burchi, / che parte sono in acqua e 
parte in terra" (vv. I9-2O), i el català: "Axi estan a vets los tartugots, / qui estan part en aygua, part en terra”. Febrer, per rimar amb glotz (it. lurchi, v. 2I), afegeix gots al v. I7 (turchs, tartes ne gots; it. Tartari né Turchi), i al v. I9 tradueix burchi, que designa unes embarcacions petites, una mena de xalupes, per tartugots, ${ }^{29}$ augmentatiu de tartuga, que fa sentit plenament perquè també es poden estar amb mig cos fora de l'aigua i mig a dintre. Potser la vebra ('el castor', it. lo bivero) del v. 22 li ha suggerit aquesta nova imatge.

En altres casos, Febrer se serveix de la seva formació cultural a l'hora de traduir. Per exemple, al cant XIV, els vv. IOO-IOI en italià diuen: "Rëa la scelse già per cuna fida / del suo figliuolo", i en català "Rea la pres per bres feell a sa dida / e a son fill". Febrer demostra els seus coneixements de mitologia afegint-hi la dida de Júpiter. No es pot descartar que li ho suggerís alguna glossa o comentari, però el seu nivell cultural no ho requeria. ${ }^{30}$ Altres exemples són V.54: “emperadriu de Babillonia vella", referit a Semíramis, el nom del regne de la qual no apareix en el text italià ("fu imperadrice di molte favelle"); XVIII.87: molto d'or traduint monton, com hem vist més amunt; XX.59: del deu Bach traduint di Baco, o XX.ı26: Yspalis traduint Sobilia, però el nom romà de Sevilla no apareix en els comentaris consultats a la base de dades del Dartmouth Dante Project.

\section{Conclusions}

$\mathrm{R}$ Recapitulant, al llarg de l'apartat anterior s'ha vist que Febrer tradueix amb la màxima fidelitat a l'original, el més literalment possible, com s'exigia a les traduccions de les obres sagrades o de gran prestigi. No és, però, una traducció verbum verbo, sinó que el traductor examina unitats de sentit i de forma estròfica, i decideix quines rimes pot mantenir respectant el significat. Així, en molts casos (III.78, Acheron; XVII.63, plus que neu; XVI.66, se etern, etc.) la tercera rima determina les dues precedents, i també s'han aportat exemples que demostren que Febrer llegia fragments més llargs, probablement tot el cant, abans d'emprendre la tasca de traducció (XVIII.99, XIX.89).

Les similituds entre la llengua de partida i la d'arribada, en alguns casos permeten a Febrer de mantenir els mots-rima gràcies a la traducció literal (per exemple, I.62-64-66; XVIII.5-7-9). Quan això no és possible, el seu domini de la llengua poètica el forneix de diverses estratègies per apartarse al mínim del text de Dante. La primera que hem vist és el manteniment dels mots italians en rima, que de vegades també són patrimoni de l'occità -la llengua poètica de la tradició trobadoresca que el mateix Febrer havia emprat en les seves poesies- (I.65 i 69, luy, amenduy), tot i que no pas sempre (I.72, bugiarts; XVII.55, tasca). Aquest, però, no és el recurs més freqüent, com tampoc no ho és que pugui mantenir els tres mots-rima del tercet. Sovint en pot mantenir un o dos, i ha de modificar l'altre vers (tornes la via croya a I.76; enamichs de Deu a III.84); en altres ocasions ha de canviar també les rimes (I.77-79-8I, XVIII.86-88-90, XVI.62-64-66). Ara bé, sempre que pot manté els mateixos mots de Dante, modificant l'ordre dels elements del vers: es desplaça a la posició de rima un element ja present en l’original -la intervenció, dones, és mínima- (XVII.58, 6r; XVIII.86; XX.74). Destaca la inversió adjectiu-substantiu: les característiques morfològiques dels adjectius li ofereixen més possibilitats de rima, i a més en resulta una estructura molt natural en la llengua d'arribada (I.77, 8I).

Els canvis d'ordre són una de les estratègies més freqüents, juntament amb l'addició d'algun mot a final de vers, en rima (e pel ribatge a XVIII.88, streta a XVIII.96), sovint inspirant-se en el context

29. Hem esmenat la lliçó del ms., "targugots".

30. Per a un estudi sobre el recurs a l’exegesi dantesca per part de Febrer, vegeu Parera (en elaboració).

Magnificat CLM 7, 202O, I4I-I64. ISSN 2386-8295 
(comjoyosa a I.79). És molt habitual, també, que el traductor es vegi forçat a alterar la part final d'algun vers per la rima, cercant alguna fórmula de significat similar al del text italià (tornes la via croya a I.76, aytal martir li part a XVIII.95, per cell qu'es mon govern a XVI.62). En aquests casos també intenta emprar mots dantescos, encara que apareguin en un altre vers (de qui est ben fart a XVIII.99, paraula vertedera a XIX.89). De vegades, però, només li cal canviar el gènere o el nombre d'algun dels mots-rima, com a XVIII.8 i io (ripa dura, le mura), en què es conserven els mateixos mots en rima (ribaz dur, del mur), tot i que la rima en si canvia (vegeu també III.77 i 79).

El recurs a la llengua occitana, tant des del punt de vista lèxic (croya a I.76, volon i bateu a III.74 i 82, eu a XVII.59, maus a XIX.IO5) com morfològic (potestatz i creyats a III. 5 i 7 , percebuts a XVII.54), li permet enriquir les possibilitats de rima, com ja va observar Riquer (I964: IIO) i com s'ha mostrat a [2] i [3].

A l'hora de decidir quines rimes manté el traductor, el sentit és determinant. Quan hi ha antropònims, topònims o gentilicis en rima no pot reformular el vers, sinó que intenta mantenir el mot en rima (Troya a I.74, Acheron a III.78, lombarts a I.68), encara que hagi de canviar els altres dos; si la rima és impossible, desplaça el nom a l'interior del vers (Lenno a XVIII.88, Po a XX.78).

Les estratègies que acabem de veure per a la rima també s'apliquen al metre. Així, trobem canvis d'ordre gràcies als quals s'obté un decasíllab amb el patró $4^{+} 6$ (tutto di pietra en de pedra tot a Inf. XVIII.2; li Colchi del monton en del molto d'or los Colchos a XVIII.87); addicions per completar el vers, que de vegades conformen un doblet sinonímic (la part e.l loch, patró 6+4, it. la parte, a XVIII.I2; fer e quasca, it. casca, a XVII.53); modificacions en la traducció (com a I.68 i 69, per mantenir l'accentuació de l'endecasillabo i arrodonir el vers; o a XVIII.I3, emprant un terme sinònim per aconseguir un decasíl·lab català: a tal semblant per tale imagine). En alguna ocasió, un canvi degut a la rima provoca una alteració per mantenir la regularitat mètrica, com a XVII.59, en què s'ha afegit el pronom eu en rima i s'ha hagut d'estalviar una síllaba a l'interior del vers (s'ha aconseguit traduint gialla en d'or).

S'han detectat diverses sèries de rimes en què es pot observar el rimari que Febrer tenia a la memòria i que ja havia emprat en les seves poesies, com I.74-76-78, XIX.IOI-IO3-IO5, XVIII.86-88-9o, en què afloren les lectures poètiques que tenia interioritzades. Així mateix, han aparegut alguns exemples de rims equívocs (recurs que també trobem en la seva obra lírica), com a XVI.62-64 (govern) o XVIII.95-97 (part).

També han sorgit un parell de casos en què les variants de la transmissió italiana justifiquen la solució del traductor (XVIII.6 i I2), i hem vist diverses solucions creatives de Febrer, que expressen en altres paraules el sentit del text dantesc. A banda de les que s'han enumerat al final de l'apartat anterior, espigolant entre els passatges que ens han servit per il.lustrar com traduïa, trobem feran gran carnatge traduint a morte dienno (XVIII.9O), un molt gran trepig traslladant molte gregge (XIV.I9), enamichs de Deu traduint anime prave (III.84), d'or per gialla i blancha plus que neu per bianca più che burro (XVII.59 i 63), o si ta fama apres tu se etern traduint se la fama tua dopo te luca (XVI.66). Quan la constricció formal no li permet ésser literal, doncs, el seu domini dels recursos poètics i lingüístics li permet ser creatiu mantenint-se fidel al sentit.

Aquesta selecció d'estratègies del traductor il-lustra, sobretot, dues qüestions. Febrer era un poeta destre, entrenat en la lectura i la pràctica del trobar ric i de gèneres de gran complexitat versificatòria (com ara el lai líric), i aquesta perícia és a l’arrel de la seva traducció de Dante: per això es devia atrevir a fer-la en vers i en terza rima. Emular una obra d'aquesta dificultat i amb aquest prestigi no volia dir recrear-la amb llibertat com ho faria un poeta actual, sinó retenir-ne al màxim allò que en resulta admirable per a un artífex medieval: la mesura del vers i la rima. La traducció d'Andreu Febrer s'ha de jutjar en proporció a aquesta voluntat d'imitar la perícia d'un "fabbro del parlar materno". 


\section{Obres citades}

Alòs Moner, Ramon d'. I92I. 'De la primitiva traducció catalana de la Divina Commedia', La Revista, 7: I2-I3

Badia, Lola. 1973-74. 'Sobre la traducció catalana del Decameron de I429', Boletín de la Real Academia de Buenas Letras de Barcelona, 35: 69-IOI

Badia i Margarit, Antoni. I973. 'La versió catalana de la Divina Comèdia d’Andreu Febrer’, in La llengua catalana ahir i avui, ed. by Maria Cardús (Barcelona: Curial), pp. 44-IOI [Revision of: 'La versione della Divina Commedia di Andreu Febrer (sec. Xv) e la lingua letteraria catalana', in Atti del VIII Congresso Internazionale di Studi Romanzi (Firenze, 3-8 aprile 1956) (Firenze: Sansoni), I959, II: I-35]

Benvenuti, Anna. 2008. “"Hay serva Ytàlia, de dol castell”: traduzione e interpretazione dei canti "politici” della Divina Commedia nella versione di Andreu Febrer', in La Catalogna in Europa, l'Europa in Catalogna. Transiti, passaggi, traduzioni. Atti del IX Congresso Internazionale dell'Associazione Italiana di Studi Catalani (Venezia, 14-16 febbraio 20o8), ed. by Costanzo Di Girolamo, Paolo Di Luca and Oriana Scarpati <http://www.filmod.unina.it/aisc/attive / Benvenuti.pdf>

Brummer, Rudolf. I96o. 'Über die Eigennamen in der katalanischen Dante-Übersetzung von Andreu Febrer', Zeitschrift für romanische Philologie, 76: 23I-46 <https://doi.org/IO.I5I5/ zrph.Ig60.76.3-4.23I>

Brummer, Rudolf. I966. 'Dante in der katalanischen Literatur bis zum Ausgang des I5.

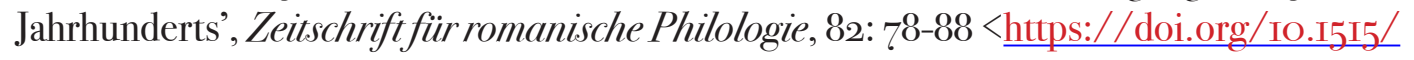
zrph.Ig66.82.I-2.78>

Brummer, Rudolf. I986. 'Un passatge de la Divina Commedia de Dante en dues traduccions catalanes', in Estudis de literatura catalana en honor de Josep Romeu i Figueras, ed. by Lola Badia and Josep Massot i Muntaner, 2 vols (Barcelona: Publicacions de l'Abadia de Montserrat), I: I33$4 \mathrm{I}$

Cabré, Lluís. I987. 'El conreu del lai líric a la literatura catalana medieval', Llengua \& Literatura, 2: $67-$ I32 $<\underline{\text { https://go.uv.es/RMoYYER }>}$

Cabré, Lluís. 1998. ‘Notas sobre la memoria de Santillana y los poetas de la Corona de Aragón’, in 'Cancionero'. Studies in Honour of Ian Macpherson, ed. by Alan Deyermond (London: Queen Mary and Westfield College), pp. 25-38

Cabré, Lluís. 2007. 'Andreu Febrer, fabbro i lector', in From the 'Cancioneiro da Vaticana' to the 'Cancionero general'. Studies in Honour of Jane Whetnall, ed. by Alan Deyermond and Barry Taylor (London: Queen Mary, University of London), pp. IO3-I4

Cabré, Lluís. 2008. Review of: Martin J. Duffell Syllable and Accent: Studies on Medieval Hispanic Metrics (Queen Mary, 2007), Llengua \& Literatura, 19: 440-43 <https://go.uv.es/ 7wlgovQ>

Cabré, Lluís; Torró, Jaume. 20I5, 'La poesia d’Andreu Febrer: el trobar ric i el Dante líric', Medioevo Romanzo, 39: $5_{52-65}$

Cabré, Lluís; Torró, Jaume, en premsa. 'Andreu Febrer: signes d'innovation dans la poésie catalane du XIVe siècle', in La Réception des troubadors en Catalogne, ed. by Miriam Cabré, Sadurní Martí 
and Albert Rossich (Turnhout: Brepols)

Cantavella, Rosanna. 202Oa. 'Versus leonini, lleonisme, léonime: la rima de dues sílllabes en la teoria poètica trobadoresca, amb els seus contraparts llatí i francès', Revista de Literatura Medieval, 32. En premsa

Cantavella, Rosanna, 202Ob. 'La teoria dels rims diccionals als manuals poètics trobadorescos i el seu context', Lecturae Tropatorum, I3: I-43 <http://www.lt.unina.it/Cantavella-2020S.pdf $>$

Cardona, Osvald. 1953. 'La Divina Comèdia en català', Butlletí de la Societat Catalana d'Estudis Històrics, 2: 95-96 < $\underline{\text { https://go.uv.es/LLfIJG4 }}>$

Cátedra, Pedro M. (ed.). 2ooo. Enrique de Villena Obras completas (Madrid: Biblioteca Castro), III: Traducción y glosas de la 'Eneida', libros IV-XII. Traducción de la 'Divina Commedia'

Closa Farrés, J. r99o. 'Lo dolç cant: entorn de la traducció de la Divina Comèdia de Dant Alighieri per Andreu Febrer (I429)', in Estudis de Llengua i Literatura Catalanes (Barcelona: Publicacions de l'Abadia de Montserrat), xx: 47-55

Comerma i Vilanova, J. I923. Història de la literatura catalana (Barcelona: Políglota), pp. 194-96

Contreras, Antonio. 20oo. 'A propósito de la Commedia de Dante en la traducción catalana medieval de Andreu Febrer', Revista de Poética Medieval, 5: II-25 〈https://go.uv.es/WetOzOz $>$ [Revision of: Contreras Martín, Antonio; Andreu Lucas, Maribel. 200o. "'A te convien tenere altro viaggio". L'oportunitat de llegir plenament la Commedia de Dant en la traducció catalana d'Andreu Febrer', Quaderns. Revista de traducció, 5: 45-54]

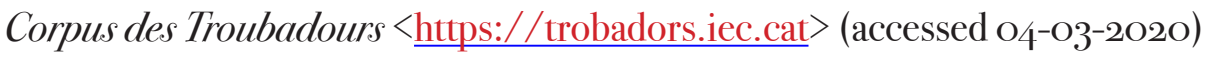

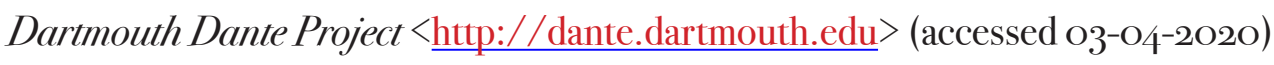

DCVB: Alcover, Antoni M.; Moll, Francesc de B. 1926-68, Diccionari català-valencià-balear, IO vols (Palma: Moll) < $\underline{\text { http://dcvb.iecat.net }}>$ (accessed O4-O3-2O2O)

DECLC: Coromines, Joan; Gulsoy, Joseph; Cahner, Max. I980-200I. Diccionari etimològic $i$ complementari de la llengua catalana, Io vols (Barcelona: Curial Edicions Catalanes; La Caixa)

Di Girolamo, Costanzo. 200I. 'La Divina Comèdia en català', L'Espill, 7: I3I-40 [Italian version:

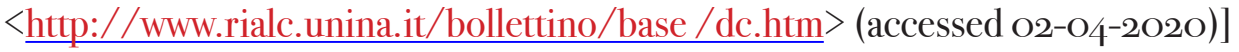

Di Girolamo, Costanzo. 2003. 'La versification catalane médiévale entre innovation et conservation de ses modèles occitans', Revue des Langues Romanes, IO7: 4I-74

Duffell, Martin J. 2007. Syllable and Accent: Studies on Medieval Hispanic Metrics (London: Department of Hispanic Studies, Queen Mary and Westfield College, University of London)

Farinelli, Arturo. 1922. 'Dante in Ispagna nell'Età Media', in Dante in Spagna, Francia, Inghilterra, Germania (Dante e Goethe) (Torino: Fratelli Bocca), pp. 30-I95

Franquesa i Gomis, Josep. I92I. 'Nota sobre la Comedia del Dant a Catalunya', Catalana Revista, 4: $387-90$

Fratta, Aniello (ed.). 2005. Jordi de Sant Jordi Poesies, Els Nostres Clàssics B, 26 (Barcelona: Barcino)

Fulquet, Josep M. I999. 'El primer cant de l'Inferno a les versions d'Andreu Febrer i de Josep Maria de Sagarra: una anàlisi de traducció', Quaderns: Revista de Traducció, 4: 95-II6 < $\underline{\text { https://go.uv. }}$ $\underline{\text { es/ujMkFf2 }}$ > 
Gallina, Anna Maria. 1957. 'Una traduzione catalana quattrocentesca della Divina Commedia', Filologia Romanza, 4: 235-66

Gallina, Anna Maria (ed.). 1974-88. Dante Alighieri Divina Comèdia, versió catalana d’Andreu Febrer, 6 vols, Els Nostres Clàssics A, IO6, IO7, II2, II6, I2O, I24 (Barcelona: Barcino)

Garcia Silvestre, M. 1932. Història sumària de la literatura catalana (Barcelona: Balmes), pp. I9O-9I

Gómez, Francesc J. 2OI3. El 'Tractat de les penes particulars d'infern' de Joan Pasqual: estudi i edició crítica (unpublished doctoral thesis, Universitat de Girona) $<$ http://hdl.handle. net/10803/135057>

Gómez, Francesc J. 20ı6a. "Lo Dant o la glosa”: aparats exegètics de la Commedia en la Catalunya de mitjan segle XV', in Els manuscrits, el saber i les lletres a la Corona d'Aragó, 1250-1500, ed. by Lola Badia, Lluís Cifuentes, Sadurní Martí and Josep Pujol (Barcelona: Publicacions de l'Abadia de Montserrat), pp. I6I-94

Gómez, Francesc J. 20I6b. 'Dante en la cultura catalana a l'entorn del Casal de Barcelona (I38II4IO/I2)', Magnificat Cultura i Literatura Medievals, 3: I6I-98 <https://doi.org/IO.7203/ MCLM.3.8433>

Gómez, Francesc J.; Pujol, Josep (ed.). 2009. Ausiàs March, Per haver d'amor vida, Biblioteca Barcino, 3 (Barcelona: Barcino)

Griera, Antoni (ed.). I92I. Diccionari de rims de Jaume March (Barcelona: Institut d'Estudis Catalans)

Letizia, Michela. 2007. 'La traduzione della Divina Commedia di Andreu Febrer: la rima di Dante a confronto con quella del suo traduttore', La parola del testo, II.I: 83-II4

Letizia, Michela. 20o8. 'Lieve, leus: la levità della traduzione e nella traduzione della Divina Commedia di Andreu Febrer', in La Catalogna in Europa, l'Europa in Catalogna. Transiti, passaggi, traduzioni. Atti del IX Congresso Internazionale dell'Associazione Italiana di Studi Catalani (Venezia, 14-16 febbraio 20o8), ed. by Costanzo Di Girolamo, Paolo Di Luca and Oriana Scarpati $<$ http://www.filmod.unina.it/aisc/attive /Letizia.pdf $>$

Marfany, Marta. 20I3. 'La llengua poètica del segle XV a través d'una traducció: Requesta d'amor de Madama sens mercè, in Actas del XXVI Congreso Internacional de Lingüística y de Filología Románicas. 6-11 de septiembre de 2010, Valencia, ed. by Emili Casanova and Cesareo Calvo (Berlin; Boston: De Gruyter), vIII: 375-84 <https://doi.org/Io.I5I5/9783IIO30003I.375>

Marfany, Marta. 2OI7. 'Poetic tradition and the voice of the translator: The first verse translations of Dante's Commedia', Enthymema, I9: 5-I6 <https://doi.org/IO.I3I30/2037-2426/910I >

Miquel i Planas, Ramon. I9II-I4. Bibliofilia: recull d'estudis, observacions, comentaris i notícies sobre llibres en general $i$ sobre qüestions de llengua i literatura catalanes en particular, 2 vols (Barcelona: Miquel-Rius), I: 232-33

Moore, Edward. I889. Contributions to the Textual Criticism of the Divina Commedia (Cambridge: University Press)

Muñiz, María de las Nieves. 2002. 'Le traduzioni spagnole della letteratura italiana all'epoca della Corona d'Aragona: saggio di un catalogo sistematico', in Le carte aragonesi: atti del convegno Ravello 2002, ed. by Marco Santoro (Pisa; Roma: Istituti Editoriali e Poligrafici Internazionali), pp. 53-IO2 
Nadal, Josep Maria; Prats, Modest. 1982-96. Història de la llengua catalana, 2 vols (Barcelona: Edicions 62), II: I3O-43

Par, Anfòs. 193I. 'Acotacions lingüístiques y d'estil a clàssichs menors catalans', Anuari de l'Oficina Romànica de Lingǘstica i Literatura, 4: I79-83

Parera, Raquel. 2007. 'Sobre l'edició de l'Inferno en la versió d'Andreu Febrer', in La traduzione della letteratura italiana in Spagna (1300-1939): traduzione e tradizione del testo, dalla filologia allinformatica, atti del primo Convegno Internazionale Universitat de Barcelona, 2005, ed. by María de las Nieves Muñiz (Firenze: Franco Cesati), pp. 59-7I

Parera, Raquel. 20Io. 'La versió d'Andreu Febrer de la Commedia dantesca: recursos del traductor', in Translatar i transferir: La transmissió dels textos i el saber (1200-1500), actes del Primer Col.loqui Internacional del Grup Narpan 'Cultura i literatura a la baixa edat mitjana' (Barcelona, 2007), ed. by Anna Alberni, Lola Badia and Lluís Cabré (Santa Coloma de Queralt: Obrador Edèndum; Publicacions URV), pp. I6I-78

Parera, Raquel. 20I8. La versió d'Andreu Febrer de la 'Commedia' de Dante: biografia del traductor, estudi del manuscrit, anàlisi de la traducció i edició dels cants I-XX de l'Inferno'(unpublished doctoral thesis, Universitat Autònoma de Barcelona) $<$ http://hdl.handle.net/Io803/664223 $>$

Parera, Raquel, en elaboració. 'El recurs a l'exegesi dantesca en la traducció de la Commedia d'Andreu Febrer'

Parramon i Blasco, Jordi. 1992. Repertori mètric de la poesia catalana medieval (Barcelona: Curial Edicions Catalanes; Publicacions de l'Abadia de Montserrat)

Pascual, José Antonio. 1974. La traducción de la 'Divina Commedia' atribuida a D. Enrique de Aragón: estudio y edición del Infierno (Salamanca: Universidad de Salamanca)

Pazzaglia, Mario. 1990. Manuale di metrica italiana (Firenze: Sansoni)

PD: Levy, Emile. 1923. Petit Dictionnaire provençal-français (Heidelberg: Carl Winter)

Petrocchi, Giorgio (ed.). I966. Dante Alighieri La Commedia secondo l'antica vulgata, 4 vols (Milano: Mondadori)

Piredda, Claudia. 2007. 'Per una edizione critica della Comèdia di Andreu Febrer: il Paradís', in La traduzione della letteratura italiana in Spagna (1300-1939): traduzione e tradizione del testo, dalla filologia all informatica, atti del primo Convegno Internazionale Universitat de Barcelona, 2005, ed. by María de las Nieves Muñiz (Firenze: Franco Cesati), pp. 73-88

Prats, Modest. I988. 'Per a una valoració de la versió catalana de la Divina Comèdia d'Andreu Febrer', in Studia in honorem prof. M. de Riquer (Barcelona: Quaderns Crema), III: 97-IO7

Pujol, Josep. I988-89. 'Els versos estamps a la lírica catalana medieval', Llengua \& Literatura, 3: 4I87 <https://go.uv.es/Q 3 LvXcn $>$

Pujol, Josep. 20I4. 'Dante Alighieri: la Comèdia', in Història de la literatura catalana, ed. by Àlex Broch (Barcelona: Enciclopèdia Catalana; Editorial Barcino; Ajuntament de Barcelona), II: Literatura medieval (II): segles XIV-XV, ed. by Lola Badia, pp. I54-55

Pujol, Josep, en premsa. 'Les vers estramps, d'Andreu Febrer à Ausiàs March', in La Réception des troubadors en Catalogne, ed. by Miriam Cabré, Sadurní Martí and Albert Rossich (Turnhout: Brepols) 
Quer, Pere. 200o. 'Andreu Febrer, contemporani d'Ausiàs March', Reduccions Revista de poesia, 72: 8I-99

Renesto, Barbara. 200I. 'Note sulla traduzione catalana del Decameron del I429', Cuadernos de Filología Italiana, núm. extraordinari: 295-313

RIALC: Repertorio informatizzato dell'antica letteratura catalana (Napoli: Università di Napoli Federico II) <http:// www.rialc.unina.it $>$ (accessed O4-O3-202O)

Ribelles Comín, Josep. I9I5. Bibliografía de la lengua valenciana, o sea catálogo razonado por orden alfabético de autores, de libros, folletos... etc., que escritos en lengua valenciana y bilingüe, han visto la luz pública desde el establecimiento de la imprenta (Madrid: Tip. de la Revista de Archivos, bibliotecas y museos), pp. I29-39

Riquer, Martí de (ed.). I95I. Andreu Febrer Poesies, Els Nostres Clàssics A, 68 (Barcelona: Barcino)

Riquer, Martí de. I964. 'Andreu Febrer', in Història de la literatura catalana (Barcelona: Ariel), II: 92-III

Riquer, Martí de. 1978. 'Il Boccaccio nella letteratura catalana medievale', in Il Boccaccio nelle culture e letterature nazionali (Firenze: Leo S. Olschki), pp. IO7-26

Rohland de Langbehn, Regula (ed.). 1997. Marqués de Santillana Comedieta de Ponza, sonetos, serranillas y otras obras (Barcelona: Crítica)

Rubió i Balaguer, Jordi. 1953. 'Literatura catalana', in Historia general de las literaturas hispánicas, ed. by Guillermo Díaz-Plaja (Barcelona: Vergara), III: 727-930

Ruiz Calonja, Joan. 1954. 'Andreu Febrer', in Història de la literatura catalana (Barcelona: Teide), pp. $263-69$

Sansone, Giuseppe. 20or. 'Traduzione medievale e traduzione moderna: la Commedia di Febrer (I429) e di Sagarra (I94I)', La Parola del Testo, 5: 29I-3O4

Sapegno, Natalino (ed.). 2002. Dante Alighieri La Divina Commedia, 6th edn (Firenze: La Nuova Italia)

Serra-Baldó, Alfons. I935. 'El decasíl-lab català i l'endecasillabo italiano', Quaderns de Poesia, 3: $2 \mathrm{I}-29$

Tavani, Giuseppe. 1979a. 'Sulla versificazione di Andreu Febrer, I: Strutture strofiche e metriche', Estudis Universitaris Catalans, 23: 56I-72 <https://doi.org/IO.I5I5/iber.I979.I979.9.I2>

Tavani, Giuseppe. r979b. 'Sulla versificazione di Andreu Febrer, 2: Le strutture ritmiche', Iberoromania, 9: I2-20 <https://doi.org/IO.I5I5/iber.I979.I979.9.I2 $>$

Todesco, Venancio. $195^{\mathrm{I}}{ }^{-}{ }^{2}$. 'La prima edizione della versione catalana della Divina Commedia e le sue vicende', Atti e Memorie dell'Accademia Patavina di Scienze, Lettere ed Arti (Padova), 94: I29-39

Torró, Jaume. 2005. 'Ausiàs March, falconer d'Alfons el Magnànim', in Actes del X Congrés Internacional de l'Associació Hispànica de Literatura Medieval, ed by Rafael Alemany, Josep Lluís Martos and Josep Miquel Manzanaro (Alacant: Institut Interuniversitari de Filologia Valenciana), III: I52I-38

Torró, Jaume (ed.). 20o9. Sis poetes del regnat d'Alfons el Magnànim: Lluís de Requesens, Bernat Miquel, Martí Garcia, Rodrigo Dies, Lluís de Vila-Rasa, Francesc Sunyer, Els Nostres Clàssics B, 29 (Barcelona: Barcino) 
Torró, Jaume. 20I4. 'La poesia cortesana', in Història de la literatura catalana, ed. by Àlex Broch (Barcelona: Enciclopèdia Catalana; Editorial Barcino; Ajuntament de Barcelona), II: Literatura medieval (II): segles XIV-XV, ed. by Lola Badia, pp. 26I-352

Vidal y Valenciano, Cayetano. I869. 'Imitadores, traductores y comentadores españoles de la Divina Comedia', Revista de España, IO: 2I7-34, 517-33

Vidal y Valenciano, Cayetano (ed.). I878. Dante Alighieri La "Comedia" de Dant Allighier (de Florença) traslatada de rims vulgars toscans en rims vulgars cathalans per N'Andreu Febrer (siglo xv) (Barcelona: Librería de D. Álvaro Verdaguer) 